\title{
The Changing Postmodern University
}

\author{
Chi Hong Nguyen \\ Center for Foreign Languages, Can Tho University \\ Campus 2, 3/2 Street, Can Tho City, VIETNAM
}

E-mail: nhchi@ctu.edu.vn

\begin{abstract}
While modernism with its principles lying in reason and metanarratives was commended for rationalism and absolute truth yielded in science and technology, postmodernism rejects scientific achievements which have brought both benefits and disasters to life and widened social stratification. It describes a rejection of such fundamental Western philosophies as Euro-centricism, metaphysics, authoritarianism and domination. It denies the existence of objective knowledge, the consistence of the self and rationalism. On the one hand, the reality we live in is said to be full of holes with scientific establishments with which scientists have created for a better life, and on the other in views of ethics many of us have become skeptical about the unique existence of truth. Higher education no longer seeks the unity of culture and consensus of communal communication, but accepts to challenge itself to criticisms and to swim in global competition flows. Knowledge from universities which has both lost its ivory power and broken its science-exclusive preserving border becomes functional when students aim to ingest what they want to ingest as they find it useful for their global civic participation. Universities must consequently become a pioneering cradle in the production of new knowledge for society and human beings, and they are mandated to provide global-adaptive knowledge to global moving students. While modernist education tried to educate students for citizenship and fixed jobs, postmodernist education is believed to train them for uncomfortable uncertainties and the ability to live with chaos. Postmodernism changes our mindset. It changes higher education.
\end{abstract}

Keywords: Modernism, Postmodernism, Postmodernism in education, The postmodern university

\section{Introduction}

"Postmodernism" as a philosophical term itself refers to real phenomena and to an intellectual movement which is precisely called "post-structuralism" that developed in France in the 1960s (Cahoone, 2003). It is a discontinuity with the modern era which celebrated technological successes from the Enlightenment, and it connotes an escape from the legacy of Euro-centric metaphysics, authoritarianism and domination. It denies the possibility of objective knowledge, single and fixed meaning of language, the unity of the self and rationalism. It rejects most of the fundamental philosophies in Western civilization in many socio-economic and political aspects as well as education. It is inevitable that this new language and its thoughts cause confusion, ambiguity and discomfort. It sometimes poisons us. The rejection of realist knowledge and absolute truth is of most concern in education which traditionally defines knowledge as the remembering of previously learned material or the body of truth, information, and principles acquired by humankind or interpreted information that can be used. This may involve the recall of a wide range of material, from specific facts to complete theories, but all that is required is to possess a great memory capacity to memorize a stock of information, and it is impossible for students as they are not a walking encyclopedia. Together with the influences of globalization and market-oriented consumerism, education is now changing itself, and so is higher education in the new times. This article aims to present the author's notes on such a change as a mandate at the post-modern university in many aspects. This post-modern university, of course, originates from any existing university which is operating in this changing world.

This article starts with a brief introduction to the historical move from modernism to postmodernism with a focus on the evolvement of knowledge from being considered as rationalism and totalization to being seen as a special kind of story and discourse which favors fragmentation and marginalized voices in higher education. By breaking down the abstract concept of postmodernism and its ethos, the discussion goes further with some notes on the view of knowledge at the postmodern university which must turn to be more flexible and adaptive to the changing world, and education is going through major changes in its objectives, contents and methods (Edwards $\&$ Usher, 1994). The postmodern university must then be changing its education inquiries under influences of the changing philosophies. 


\section{A Historical Outlook from Modernism to Postmodernism}

Not only is postmodernism a philosophical movement but its doctrines have intruded many other aspects such as arts, dance, education, literature, music, politics and theology (Cahoone, 2003; Hicks, 2004; Hutcheon, 1989; Sim, 2005). The term "postmodern" is said to sporadically occur somewhere back in the 1870s when the English painter John Watkins Chapman proposed that a new school of art go beyond French Impressionism (Sim, 2005), and has captured a strong attention since the later half of the twentieth century. In 1914 Thompson used it to mean changes in attitudes and beliefs under criticism of religion, indicating an escape from doing the right thing for a wrong reason in theology. It was then used in 1917 by Rudolf Pannwitz, who described a new form of European military culture after the War, and who further developed the theme of "nihilism" proposed by Friedrich Nietzsche and judged its decadence in the context of the twentieth century's Western culture (Cahoone, 2003; Sim, 2005). This philosophical movement puts forward a reassessment of such previous fixed values as equity, peace, verity, justice, and spells the end of metaphysics. It assumes that philosophical understandings could originate from the existential self including the living individual, their emotions and activities. Such a self is closely related to an existential attitude. This term again appeared in 1921, 1925 and 1926 to describe a new form of art and music. This so-called "postmodern" ideological trend was continuously mentioned in 1934 by Fredireca de Onis, who in his book Antología de la Poesía española e hispanoamericana: 1882-1932 referred to a negative reaction to literary modernism (Cahoone, 2003). This word once again appeared in 1939 to mean two different things: by Bernald Iddings Bell as a failure of the secular modern world and a return to religion though he did not really mean like the understanding of present postmodernists, and by Arnold Toynbee in $A$ Study of History as a historic reference from 1875 as a cultural decline to the post-World War 1, as a popularity of mass society where the normal working class played a more important role than the capitalist class, and as a collapse of the Enlightenment rationalism. It was then used during the 1950s and 1960s as the reaction to literary modernism, and reached its peak in the 1970s as the dissatisfaction with modern architecture. It entailed an analogous use in architecture with a close connection to the analysis of post-industrial society and knowledge-, service-based economies after the Second World War. In fact, Charles Jencks in his book The Language of Postmodern Architecture in 1977 was criticizing modern architecture which had not satisfactorily served public concerns. The Pruitt-Igoe complex in St Louis, Missouri, which was dismantled at 3.32 p.m. on July 15, 1972 (Jencks, 1986), proved such a failure when the public had rejected the modern style which encapsulated a stronger focus on volume of architectural structures, balance and rejection of ornamentation. By contrast, postmodern architecture favored an eclectic trend freely mixed with personal preferences combining both the old and new styles as an emerging international style, and with its double-coded quality it tended to please both professional architects and the public comfort.

Reactions to modernism came in different aspects. For example, the rejection of modernism has too become popular in environmental movements in the late twentieth century with the appearance of Green political parties in Western countries (Sim, 2005) and the reactions in both international conferences and local events to the catastrophic aftermaths of industrialization and modernization culminating in climate change. In addition to environment, artists like Michael Fried claimed that the very nature of modernist painting was to dig into materiality and was subject to the tyrannical interests of mass culture which somehow resisted the manipulating effects of popular culture (Trodd, 2005). In terms of philosophy, French post-structural philosophers adopted this term in the 1980 s to describe a reaction to rationalism, totalism and utopianism and to criticize the justification of knowledge by rooting it in first principles or sense-data or both. The main theoretical avowal of postmodernism is its rejection of grand theories or universal theories of Western culture due to their lost credibility and its disdain in its different shapes and forms (Sim, 2005).

The last quarter of the twentieth century has seen the debate between modernist and nostalgic theorists who favored humanism and rationalism, and who found their alliances in positivism who based their assumptions mostly on knowledge foundation known as epistemology, and such postmodern philosophers as Barthes, Derrida, Foucault or Lyotard pointed their attacks to the modern philosophical foundation. According to Mary Klages (2007), postmodernism is a complicated term which denotes an ideological system popularly deployed since the 1980s. Klages (ibid.) recommends that the best way to approach and comprehend this ideological movement is to return to the origin of modernism and the nature of modernity which mostly rejected the obsolete Victorian artistic standards. The main characteristics of modern arts include an emphasis on impression and subjectivity in writing and how arts are seen rather than what is perceived, leading to stream of consciousness writing. Modern literary also emphasizes a tendency towards reflexivity and self-consciousness, and a rejection of the distinction between high and popular culture. Postmodernism like modernism follows most of these ideas, focusing on the rejection of high and low culture, to genre distinctions, placing an emphasis on pastiche, parody, irony and pun. 
Modernism refers to the twentieth century's aesthetic movement while modernity implies a set of philosophical, political and ethical ideas. The term "modern", which was assumed to first appear in the nineteenth century's sociology, was used to indicate a new time juncture from antiquity (ibid.; Nguyen, 2006). The word "modern" had its origin from the Latin word "modo" (of today) used popularly in the fifth century to denote such a separation of the Western ideology from the set of influential old Roman ideas (Cahoone, 2003; Oden, 1992), and later adopted a new meaning of progress, a tactful possession of truths compared to those in antiquity (Bock, 1979). As Frederic Jameson (1981) notes, modernism and postmodernism are cultural movements which have accompanied capitalism in three main cultural phases. The first phase is related to the occurrence of market capitalism in the eighteenth century through the late nineteenth century in Western Europe, the UK and the US while the second stage that last from the late nineteenth century to the mid twentieth century is mostly associated with monopoly capitalism. The third phase is marked as the present time with the proliferation of multinational and consumer capitalism. Historically speaking, modernism marked quite a long era in the world's history with its inception right in the Enlightenment which celebrated the success of the French Revolution in 1789 lasting until the mid twentieth century which saw the collapse of the Berlin Wall in 1989 (Oden, 1992). Baudrilla (1994) and Klages (2007) yet assume that modernism last from 1750 to the end of World War Two while Bell (1976) insists that it appeared from the end of the nineteenth century to the first few years of the 1960s with its peak from 1890 to 1930.

Modernism posed a debate over pre-modern and new values when the former showed a high respect to the existence of an outer space supernatural body who was deemed to be invisibly omniscient. Modernists criticized such a belief when they based their judgment on technological advances of the time which simultaneously opened doors to new political, social, ethical and aesthetic values with a profound confidence in reason and individualism (Hicks, 2004). During the Enlightenment, stemming from the objectivity of reality proved by scientific evidence, philosophers searched for absolute truths in order to form universal theories and create a logically appropriate social mechanism (Smart, 1990). The dialectics of the self was insisted as a foundation to understand the workings of nature on a larger scale, and modernism went even further by pointing out a remark in randomness and ephemera (Harbemas, 1987). According to Flax (1990), the basic ideologies of modernism characterized in the Enlightenment espouse the existence of the self who is structured consistently and perceives his internal workings and his relations to the external world by applying universal principles. Thanks to scientific advances, modernists started their philosophical reasoning from found rules in nature instead of unknown supernatural forces and mysticism, and they placed a focus on human autonomy and ability to form one's character, considering an individual as a sovereign entity and unit of reality instead of pre-modern thinking of "dependence and original sin" (Hicks, 2004, p. 7). As a result, individualism became a central topic in the study and discussion of human ethics. Enlightenment thinkers based their reasons mostly on the foundation of science, and hence knowledge which was withdrawn from scientific establishments became an epistemology of reason, and individualism seemed to be a catalyst for the growth in human spiritual and material life. As Hicks (ibid.) indicates, it was used in politics and yielded liberal democracy, in economics and yielded free markets and capitalism, in material production and yielded technological successes, and in the understanding of human beings and yielded medical breakthroughs.

Modernism is largely about order and rationalism. The main ethos includes a creation of rationality which is conductive to a creation of order, and it supposes that society should be ordered so as to function better and sustain stability. This grand theory was based on scientific successes which led us to industrialization, materialism, urbanization, and colonization. The mainstream thoughts were mostly in favor of the advantaged, and "others" would include irrationalism, lack of civilization, non-whites, non-Eurocentrism, homosexualism, and ethnic minorities all of which had to be eliminated. Therefore, such concepts as "disorder", "chaos" and the like that may disrupt social order are mostly filtered and stopped. Such an emancipatory regime was maintained as the central foundation for a rational society entailing its authoritarianism and political power. However, the World Wars, colonial barbarity, technological dark sides, and pragmatism have caused doubt in our present lives, and not everyone may feel happy with their one-time celebrated scientific or so-called modern achievements and applauses. This is where the voice of postmodernism is heard.

\section{The Postmodern Ethos}

In essence, postmodernism negates modernists' basic assumptions in regard to the existence of objective knowledge and absolute truth. While modernism was founded on a belief that there was an objective reality existing independently from one's thought and appearing almost in the same way to anyone, and such a reality could be expressed objectively through truth, science and knowledge, knowledge in postmodernism is said to be just a special story, text and discourse with intended wordy arrangements in forms of signs. In other words, 
postmodernism rejects the existence of absolutely objective knowledge since what is called knowledge is merely constructed from words and their assigned meanings in a certain culture which views the world in different points of view. Such a system is judged on the basis of beliefs of those in power in order to support them in return, and hence those beliefs and truths which are justified as standards in one country or group cannot be seen as an equivalent in another. Postmodernism goes even further by stating that in Eurocentric cultures, which have forced their ideologies onto other cultures by political, economic forces, military invasions, and by those who are in power and in authoritarian aristocracy, have dominated and controlled their mainstream and orthodox thoughts and beliefs in politics, culture and science, making objectivity hardly objective (Lemke, 1994).

Postmodernism rejects the Enlightenment project in many fundamental ways and sees itself as anti-philosophical with a strong rejection of traditional philosophical movements. According to Hicks (2004, p. 6), postmodernism is metaphysically anti-realist as it holds an impossibility "to speak meaningfully about an independent existing reality", replacing a social-linguistic construction of reality, and epistemologically rejects the insistence of an independent existing reality, refusing the role of reason as a means to acquire objective knowledge in reality. It denies the legitimacy of the whole course of epistemology and the attempt to justify knowledge. Postmodern beliefs lie in the collectivism of human nature as individual identities are largely formed by the influence of social groups. It also emphasizes relations of conflicts between these groups and how these conflicts can be resolved by the use of force which in turn leads to relations of dominance, submission, and oppression. It argues that what was normally believed to be true and standard was mostly based on the political convenience and dominance of European imperialism of the past. As such, postmodern ethics stands for a deep sympathy for those who are oppressed and disadvantaged in these conflicts.

Postmodernism too denies the existence of reality and considers it as a real illusion which is created by the language we use. What we are mostly engaged in is just the recreation of simulacra where "the image of reality bears no relation to any reality whatever: it is its own pure simulacrum" (Baudrillard, 1988, p. 170). This is the reason why there could be no single reality, and the language we use seems to define our knowledge and the way we perceive it (Hardy \& Palmer, 1999). As Nazemzadeh and Kritsonis (2007) simply put, postmodernism fights against the four central themes of the Enlightenment philosophy being the existence of an autonomous self, fundamental epistemology, universal theories, and the belief that social and ethical advances could be made by science. It claims to be associated with the logic of divergence and difference which is incompatible with the logic of democracy (Blackmore, 1999 cited in Nazemzadeh \& Kritsonis, 2007).

Postmodernism lies in different guises one of which is the expression of skepticism about authority, wisdom, cultural and political practices that undermines philosophical theories in support of the possession of truth or judgment criteria for truth (Sim, 2005). Such a skeptical attitude is also known as anti-foundationalism which challenges the foundation of discourse for truth. Postmodernists' reaction to structuralism is seen as an expression of skepticism towards authority and its methods. It raises questions about cultural certainties in structuralism with the belief that the world is "intrinsically knowable" (Sim, 2005, p. 4) which offered us methods to unlock the workings of the world based on certain fixed rules. The linguistic model by Ferdinand de Saussure (1966) suggested a linguistic system of rules and internal grammar that governed how linguistic elements came into interactions. Language was seen as a system of different elements of signs, the signified and the signifier in which each element was dependent on relations to others. The meaning of a word was therefore predetermined by its existence with other surrounding words within a universal grammar. This system implied a relative stability in languages and the production of meaning which could well be predicted in a linguistic community. This system was also applied to other systems in life inducing that every system had rules to govern the operation. Yet, postmodernism describes language as a jar containing meaning which becomes independent from realities and is not dependent upon the will of one self. It sees culture as a system of signs which decide reasoning and control people's activities after the language. Postmodernism rejects the neatness and tidiness of structuralism, assuming that there would be no loose ends, and grand narratives tend to fall into certain structures with their universalities which may not be always true in every situation, and with specific genres which cannot be applied to all. Postmodernism believes that it should be more important to appreciate differences, dissimilarity and unpredictability of analysis than just to find out similar rules within operations and predict results with certainties. One of the most famous instigators of postmodernism is Jacques Derrida, who began to analyze Husserlian phenomenology which attracted self-undermining issues in Husserl's fundamentalism and further semiosis. According to Derrida (1973), signs are always associated with their meanings which can be mediated and generated endlessly with unpredictability. Derrida denies that there is immediate reception of the given text, and what the author of a text wants to imply is not completely conveyed to a reader's mind as the original meaning, or as he states "There is nothing outside the text". Human beings encounter the world with real 
referents through texts and representations. Also, we cannot completely analyze an individual's perception process from language if we have no idea of the language discourse that the culture of that person uses to communicate. Language discourse of postmodernism bases its language decode on intertextuality which comes from different aspects of language and culture such as linguistic visual-audio signs, assigned meanings, referents, and cultural practices and the like.

Deconstruction is hence against the system-building argument of structuralism, the predictability and stability of language. Signs are not predictable entities and do not entail a unified meaning. There is instead a slippage of meaning because words contain echoes and traces of other words, and meaning seems to "evaporate" (Sim, 2005, p. 5) as soon as it happens in spoken or written language rather than holding a fixed meaning over time. In other words, linguistic meaning is not a fixed system, but différance (a neologism from the French word différence which means both difference and deferral) is always applied to challenge the assumption of Saussaure's ethos of semiological difference, to prevent the establishment of the presence of meaning in communication, to indicate the closure of presence, and to fight against totalization and grand theories which claim to explain everything. Instead, little narratives are celebrated where they are linked to one another on a tactical basis by different groups to achieve different purposes (ibid.). Postmodernism considers little narratives as a way to create and disseminate knowledge and to break down "the monopoly exercised by grand narratives (ibid., p. 8). These small stories are seen as the primary means of scientific inquiries to search for paradoxes, instabilities and the unknown rather than just create another grand theory for authoritarianism.

Yet, postmodernism is not only concerned with signs. It also considers that every object is complex, and the complexity of a phenomenon is generative and able to grow. Completeness of phenomenon and consistency of a system are therefore impossible, and analysis does not stop (Cahoone, 2003). Totalization, stability and order in modern societies are often intended to remain via legitimating myths and grand narratives of modernism (Lyotard, 1984). It posits that every social aspect including science as the basic form of knowledge depends on these metanarratives about a dominant culture with a political purpose. The abuse of these grand stories is exerted to hide the other sides being disorder, instability or minority. In contrast, postmodernism supports these "the others", and petits recits (small stories) are examined from the various angles of temporary, randomness, objection to totalization, to objective knowledge and rationalism. It fights against the unity of the world, knowledge, the self and society. In fact, it sees knowledge as a human product and "a selection from a phenomenal or semiotic complexity" (Lyotard, 1984, p. 10) which we can sense by our cognition. It argues that complexity is too great to absorb, and some act of meaning and knowing must be ignored or suppressed to achieve a purpose after the text. Simply put, reality and our experience of it can be somehow seen as the product of our error and misrecognition.

In short, postmodernism is a complex philosophical movement which is involved with different counteracts to modernism in different forms. It considers truth is a myth, and reason is a dominant Euro-centric construct. Along with relativism and egalitarianism themes are voices of skepticism and rejection of metaphysics and grand theories. Yet, religious, economic and political fundamentalism with the typical example of the extreme Islamic people who are struggling against the invasion of Western cultural imperialism is trying to reassert its authority in prominence (Sim, 2005). The grand narratives that lie in these beliefs do not fade away yet. Faith turns to be the foundation in its survival. It is, therefore, probable to predict that postmodernists may find themselves in a conflict while they reject grand narratives on the one hand, but on the other they must base their reasoning on certain other fundamental explanations. In other words, postmodernism can be another grand theory.

\section{Postmodernism and Education}

Postmodernism rejects the perception that the main goal of education is to train students' cognitive ability for reason to produce a fully independent functioning citizen, but rather a citizen with a full social identity. Educational methods are through languages, so they must create a citizen who is sensitive to his or her racial, sexual, and class identity which is communicated via their language (Hick, 2004). It also opposes any oppression that offers benefits and priorities to "whites, males, and the rich at the expense of everyone else" (ibid., p. 17) because such a mode of education just serves the rights and interests of those in power. Therefore, education must be recast wholly with a newer focus on marginalized groups and the voices of those who have traditionally remained silent, and it should critically remind students of the historical sins and crimes of the colonial ones in authority. Students should be meanwhile taught to be receptive to different ways of knowledge ingestion. Postmodernism holds that all knowledge can be constructed in people's mind, it tends to be used not because of its truth, but rather because it is found useful (Delashmutt \& Braund, 1996 cited in Nazemzadeh \& Kritsonis, 2007). It also means that what is taught at school is not a mere reality but a human product of construction, so knowledge at school turns to be a matter of power or as Foucault (1977) proposes that truth has a close 
association with systems of power which in turn produce truth and sustain it at their will. Postmodernism argues that knowledge has become a commodity which may then turn to be a source of conflict amongst groups and countries, and those who control knowledge hold greater political power or as Foucault (ibid.) states, society owns its regime of truth inducing regular effects of power in a circular relation. Knowledge is often seen as a product of narratives and authoritarianism. Therefore, the existence of a body of absolute truth is not encouraged, but an appropriate approach to finding out the sources of knowledge and the appreciation of why such a piece of knowledge should be learnt must be created and nurtured. Abstract concepts do not probably exist, but they in fact refer to real phenomena.

Furthermore, market liberation and free trade with the global dominance and force mould the way knowledge is produced and disseminated. Education is seen as a commodity, and students have more liberty in choosing their courses. They tend to actively choose what to study with their self-directedness, and education is deemed to be open and provisional with its mandated customer- and industry-oriented pedagogies (Barnett \& Griffin, 1999). Knowledge, in other words, becomes functional when students often raise such questions as why they have to study a piece of knowledge, so educational policies must aim to place a focus on training students for social and vocational skills (Sarup, 1993). Further, students may start their education at a later stage where they have sufficient economic means and tend to choose different modes of schooling that suits their styles. Various class instruction modes and admission requirements and procedures, therefore, must be provided handful for them to choose from if a government really wishes to push socialization in education.

Due to one of the characteristics of globalization as flows or movements of people, ideas and goods (Appadurai, 1996; Christie \& Sidhu, 2002; Waters, 2001), knowledge can also be transported through information technology (IT), telecommunications, and the mobility of academic staff and students. IT and global communications technologies, on the one hand, make knowledge available to those who have access to them. On the other, national and international laws on copyrights and intellectual property make it hard to retrieve information. Also, as Marginson (1999, p. 21) puts it in regard to education, these technologies facilitate the growth of market exchange in which education is defined as a corporate service that must obey the economic laws of supply and demand. IT and communications technologies speed "the translation of knowledge into transmittable information", so knowledge becomes "saleable commodities". The knowledge-based economy (KBE) widens the "social inequality" and "social exclusion" (Castells, 2000, p. 68), or as in Marginson's terms (1999, p. 28) "access and exclusion", between the have and the have-not in the sense that the latter become unable to acquire sufficient education to obtain "cultural capital" (Bordieu, 1997, p. 243) which can be used to compete for their "social status" (Marginson, 2004, p. 7).

Though modernism with its age of reason and metanarratives was applauded for optimism, rationality, a search for absolute truth in science and technology, and the assumption that reception of knowledge for the true self laid the foundation for another reception of knowledge (Ward, 2003), postmodernism rejects some scientific achievements that have brought disasters to life leading to environmental disasters and mass killing. In other words, science is believed not to be an all-time tonic. Besides, the consumerism and trading in science has caused a loss of belief in the ability to measure reality and a separation amongst professions and inter-disciplines where academic people tend to go for more and more but less and less. The reality we live in is said to be full of drawbacks of scientific establishments with which scientists have tried to create for a better life, but in views of ethics many of us have become cynical and skeptical about the unique existence of objective science or it is understandable to imply that reality is there, is just given to us by its very nature. Yet, science is made, found and used by us; i.e. it does not make us.

In regard to politics, those who are in power and want to be in power aim to both increase the utility and the use of knowledge as a source of power and conciliate the dark sides of objective science bringing to marginalized groups. Such an ambivalent approach does not become concentric in sustainable development and the pedagogical course of teaching and remaining traditionally ethical codes. Or as O'Farrell (1999) states, the reality that we are given has left us doubt in the age of reason and rationality which does not necessarily save us. Therefore, it is mandated that this reality not be given to us, yet it be made by us as mentioned earlier in this text. Such a reality where we live is seemingly a simulacrum (Baudrillard, 1988), and this loss of faith in science has laid a foundation for Lyotard (1984) to define postmodernism as a loss of faith in metanarratives which have created totalization and universalization theories that mould our reality into certain fixed ways. Education is hence charged of changing its traditional pedagogies that have fitted modern times of objective truth and science based on rationality to a new mode that fits "the reality experienced by a new generation" (Hutcheson, 1989, p. vii). The new pedagogy, in the author's view, must be based mostly on students' and society-industries' needs which may be in turn changing themselves. With global flows of people, ideas, capital and politics, students 
become global citizens who will take control and may be dominated by such a force. Therefore, curricula, which on the one hand must be open and sustainable, decentralize rather just place an only focus on a hierarchy of knowledge on the other. Teaching contents must draw students to different doors to new horizons of approaching the vast space of information. Education must also pose students and administrators questions of challenging traditional assumptions of rationality, certainty and truth. Students must well be equipped with strategies to scientific inquiry methods with which they can themselves swim in the large ocean of knowledge. Such a swimmer not only knows how to swim well but is also able to gauge their ability before making the decision to swim across and understand the reason for such a decision. Further, the ends of objective science and absolute truth do not equally mean that science is spelled to its end, yet academic people start to seek for a new way to approach knowledge, or as the author believes, a deeper probe in ethical issues should be done to look into different angles of scientific inquiries to prevent their harm to life.

In addition, in view of postmodernism advances in transportation, IT and communications have brought to countries both opportunities and threats which can be considered as the dark sides of this third technological revolution. We have experienced the new times comprising of various interrelated changes on a global scale, so the ability to handle chaos and risk proactively is the required quality people should acquire to survive and develop healthily. Besides, national borders have turned to be more permeable and fragile when globalization as a process or a set of processes includes a spatial transformation in the organization of social relations and transactions (Held, McGrew, Goldbaltt, \& Perraton, 2000). Consequently, this new time of discontinuity urges people to come together to deal with the issues and their impacts by utilizing their own knowledge, a giant power and a dominant resource of prosperity and well-being (Marginson, 1999; Nguyen, 2000). In other words, knowledge is a necessary and sufficient condition for people in the new times to live and work effectively (Phan, 2000). One of the specific examples that education is supposed to train citizens to enter and take advantage of the process of global integration is the teaching of foreign languages (English), mathematics (statistics and probability), and computer literacy. Furthermore, education must, on the one hand, produce and maximize conditions for students' learning (Christie \& Lingard, 2001; Lingard, Hayes, Mills, \& Christie, 2003) to deal with unpredictability. On the other, under the influences caused by globalization, educational institutions need to be aware of social inequalities or the questions of "access and exclusion" (Marginson, 1999, p. 28), which they cannot always compensate for. They must reduce as many disadvantages as possible by providing students with two kinds of knowledge to enter the world: social and academic. Social learning builds up students' consciousness of their citizenship and civic participation, and academic learning helps engage them in understanding and applying different kinds of knowledge critically and analytically.

\section{The Postmodern University}

Under the influences of neoliberalism in trade and humanistic development, human beings have a demand for personal development with a wide choice of the nature of jobs and of their own instincts; universities need to diversify their courses with various modes of training suitable for a global need when the world's citizens tend to move across borders and multinational corporations tend to maximize their outsourcing. As Coffield and Williamson (1997 cited in Gilliam \& Kritsonis, 2007) note, universities must stay in a close association with democratic societies and their industries to meet different soaring demands from reality. University courses, therefore, must always be innovative and meet glocal (global and local) demands. These courses must equip students with knowledge of its wide spectrum which they can apply in different localities and simultaneously suit in different situations. Since knowledge seems endless and cannot exist as a closed verity, university courses must equip students with the approaches to knowledge for their own edification in addition to providing core knowledge in each profession. Students should be instructed strategies to think analytically and critically in order to ingest knowledge selectively. When postmodernism holds that knowledge does not always remain objective, what is taught at universities therefore must be constructed around the matter of those who hold power and for those who wish to hold it. Students are not passive learners, but they may think education is somehow like a product used in markets and tend to maximize the satisfaction and usefulness of such a commodity. They should be trained and encouraged to understand why they have to study that kind of knowledge and know how to study most effectively. The exercises enclosed must be as authentic and realistic as a simulacrum which students will experience somewhere in their later lives. This study skill must be trained as their long-life study skill. Therefore, university courses must intermingle the training of the five quotients: IQ (Intelligence Quotient) as a necessary quotient for them to develop their academic ability, EQ (Emotion Quotient) as a sufficient quotient for them to understand and appreciate the beauty of life and external relationships, PQ (Passion Quotient) as an exceeding quotient for them to pursue their dreams and achieve their ambitions leading to successes, CQ (Curiosity Quotient) as a catalyst quotient for them to develop the other three above quotients, and AQ (Adversity Quotient) 
as an elite quotient for them to overcome trouble and to excel other fellow students. The combination of the five quotients will help learners be able to draw their optimistic prospect for their future careers rather than just to cram simply for technical knowledge. Due to the diversification with a high distinction amongst students, university curricula need to be open and sustainable so that each lecturer in different localities can maximize flexibility in different times, and they can flexibly modify to transfer different kinds of knowledge in different classes. While modernist education tried to educate students for citizenship and fixed jobs, postmodernist education is believed to train them for uncomfortable uncertainties and the ability to live with chaos.

In addition, under the influences of globalization which entails flows of people and ideas, universities are mandated to provide global-adaptive knowledge to global students. As a result, delivery modes on campus and inter-campus must be conducted via an international language which until the time of writing the author believes has been the English language which again accounts for more than $95 \%$ of the world's patents. English should not be treated as a dominant language or as a discriminating feature amongst students, but it had better be a lingua franca which minimizes linguistic and technical gaps, helping academia come closer. Therefore, language training should not be started too late at tertiary level when students are preparing for their professional practice, but it should be begun at an early level besides adequate mother tongue training. Students will have a good skill in their native language to help with their work in their local contexts as well as in English for their international integration, i.e. they can use it for their overseas work and in multinational corporations. Besides, due to globalization, knowledge turns to be global itself. Knowledge is now not only produced and used at school settings, but it also appears in different forms in different contexts. As Gilliam and Kritsonis (2007) note, knowledge is too globally dispersed, and it is located almost everywhere. Students as self-managing consumers may retain the right and preference to reject the kind of knowledge that they do not find useful (Barnett \& Griffin, 1999). It means that higher education quickly loses its knowledge monopoly and does not exist as an exclusive domain of experts. Knowledge consumers may possess a stronger power than universities which turn to be demanded to produce further new knowledge for their survival. Pedagogies, in other words, are requested to change their teacher-centeredness to student-driven approaches which must be responsive to industries and governmental development strategies.

As a result, universities must be a pioneering cradle in the production of new knowledge for society and human beings. Different kinds of new knowledge must be done through a process of long and careful research and be verified by leading scientists. It is noteworthy that the writer does not intend to support that there must be a distinction between theoretical knowledge and practical knowledge or to examine which considers the other as a priori (Kant, 1965). On the contrary, these two kinds of knowledge must be intermingled, and either one may come first to produce the other as theory may be created by creativity and followed by practice, and experience may produce theory. It is also noteworthy that knowledge can be seen as an exercise of power of those in power, particularly of national governments, transnational corporations and international organizations who want to enforce educational institutions to produce efficient and knowledge workers to generate scientific research outputs resulting in marketable technological products (Gilliam \& Kritsonis, 2007). Consequently, though embedded with its political quality, knowledge should not entail cultural, ethnic prejudices and high slavery dependence on technologies. Instead, new knowledge had better remain purely objective in natural sciences and humanistic in social sciences. Students should be shown how to appreciate the difference and how to live with complexity rather just criticize and discriminate differences and then become their victims.

Again, higher education is now charged with the responsibility to transmit and produce knowledge for society. On the one hand, lecturers are mandated to create and search for different sources of new knowledge as requested by economic requirements from markets and they may become part-time teachers and full-time researchers (Gilliam \& Kritsonis, 2007). Together with autonomy in university management in terms of finance, curricula, assessment etc. granted by governments, traditional types of universities are now changing their jobs, facing more "multiple missions, multiple responsibilities, multiple demands, and hence open to multiple criticisms" (Lincoln, 1998, p. 2 cited ibid.). Universities administrators must be proactive in designing strategic plans for their sustainable survival, and according to Baudrillard (1994), the borders between universities and other stake holders such as governments and multiple organizations seem to be fragile. In addition, the KBE causes the workforce to move from industrial production to service industries and from the centrality of work to the centrality of consumption (Nazemzadeh \& Kritsonis, 2007). Therefore, universities must not always operate as a separate sector in society, but they should stay as an active circuit in the larger social network, responding to change and creating change for their surrounding environment. On the other, it is important for lecturers to show students how to establish their own effective and learning strategies. Socio-economic changes have created pressure on universities to educate students for service jobs and vocational skills. Besides technical training for a 
number of students, higher education is supposed to train another number of students the ability to become prospective independent researchers in many aspects of profession such as doing action research in their everyday work lives or even in nation-scale projects. Students must have the ability to sense and appreciate the good and beauty in life, and they must also be aware of what to study for what purpose, why and how to study.

The three traditional domains of educational activities, which include cognitive, affective, and psychomotor learning (Bloom, Mesia, \& Krathwohl, 1964), are still insisted in education in the new times as "the goals of the training process" (Linn \& Gronlund, 1995, p. 32). Higher education is expected to produce a more responsive intellectual workforce who can thrive and excel in a constantly changing environment in the new times. Therefore, Schon (1995, p. 27) is reasonable when pointing out that knowledge embedded in higher education should be not only "school knowledge" contained in curricula, held in the mind of teachers, and communicated by instructions to students. Instead, it must be built around a socio-constructivist conception of knowledge which is academic, practical and critical. This kind of knowledge should also be shared on a collaborative basis and constantly questioned, assessed, transformed, and managed scientifically since according to Proenza (2000, p. 2), in this increasingly complex and interdependent world, finding solutions to certain problems requires "shared knowledge and understanding, and also shared commitment among all peoples of the world." As a consequence, lecturers must be constantly encouraged to volunteer in doing research and upgrade their specialization, and they must learn to accept that universities could be a battle for knowledge debates amongst different participants who could come from outside university settings. Universities, therefore, should not seek the unity of culture and consensus of communal communication (Delanty, 2001), but accept to challenge themselves to criticisms. Knowledge from universities has both lost its ivory power and broken its science-exclusive preserving border.

University education has stepped into a new discourse full of economic concepts such as accountability, cost-effectiveness, performance indicators and quality assurance (Coaldrake \& Stedman, 1999). Changes in funding policies, especially in higher education with more autonomy in managing finance and in technology create more international competition and mobility (Girdwood, 1997; Mok \& Lee, 2003). Higher educational institutions tend not to stay fixed within their national or regional boundaries, but open doors to recruit international students and international stake holders. Simultaneously they are both disruptively and positively influenced by media, and they are viewed as necessary for the development of economic globalism and global consumerism (Carnoy \& Rhoten, 2002). Driven by this fact, it is therefore alerted that some universities market themselves as "knowledge enterprises" (Currie, 1998, p.15) which utilize marketing and managerial skills and strategies to attract international students. Many universities tend to advertise their "names" by offering sponsorships, doing charity work, and offer local authorities attractive incentives to run offshore programs. This is the process of commodification in education and the attempts to "sell" and/or "consume" available knowledge products in lucrative markets.

Finally, in the era of global neo-liberalism, the proliferation of universities benefit those with economic capital to guarantee positional and social advantage (Ball, 2002) by obtaining better education. The belief that educational institutions can choose students, and students can choose a place to study as students choose what to study on the basis of personal desire and market demands (Trnavcevic, 2004) may not always be appropriate. Although it is widely accepted that universities have certain entrance requirements, priorities and tuition structures to choose students, under the influence of neo-liberal market where privatization becomes dominant in economic activities (Hill, 2003), economic competition becomes the base to maximize their economic bottom line (Marginson, 2004). Some universities are run to maximize shareholders' profits and tend to recruit many students. This leads to the situation where there are many bogus foreign universities which are not accredited or licensed by local authorities. Those who are not well informed have to suffer from both financial and time losses. In other words, as Hill (2003) puts it in relation to marketization in education, markets exacerbate existing inequalities. Therefore, the postmodern university must itself judge its performance on a set of unanimous ethical codes of conduct which is worth taking some space in another article.

\section{Conclusion}

In a nutshell, postmodernism has created a different place full of uncertainty, instability, ambiguity and contradiction in higher education in which education is seen as a commodity for student-consumers to choose. Such a personal choice similarly remains as an individual choice for tertiary institutions to operate with full autonomy which governments charge them of. The refusal of grand narratives and the favour of little narratives seem to turn themselves to another great story in which it is believed that knowledge may be decided to be true in consumers' point of view. There seems to be no centre in the central hierarchy of scholarship, but as consumerism stands for its reason, common tradition of knowledge has turned to be pluralistic scholarship where marginalized cultures and voices could well be included in diversified forms of knowledge delivery. Further, 
knowledge consumed as a commodity and its providers begin to change their types of products to tailor students' values and interests, yet they are still fostering a cultural-political understanding of those in authority for their social and political stability in existence. In the author's mind, the collapse of the absolute truth and objective knowledge ivories has, on the one hand, helped students become suitable and fit in their social advancement, and on the other prepared them for a democratic and just society. In other words, postmodern education should be diverse first in its objectives and processes and then in its operational structures (Edwards \& Usher, 1994) in order to produce responsive knowledge workers for global civic participation in a decentering market. Postmodernism stays as a fluid concept which is neither completely right nor wrong. The postmodern university in its local standing must go with such a flow to reach a global market and it is now tasked to give a more humanistic meaning to its education delivery quality.

\section{References}

Appadurai, A. (1996). Modernity at large: Cultural dimensions of globalization. Minneapolis: University of Minnesota Press.

Ball, S. (2002). Class strategies and the education market: The middle classes and social advantage. London: Routledge.

Barnett, R., \& Griffin, A. (1999). Higher education, the end of knowledge in higher education. London: Cassell.

Baudrillard, J. (1988). Selected writings. Stamford: Stanford University Press.

Baudrillard, J. (1994). Simulacra and simulation. MI.: University of Michigan.

Bell, D. (1976). The cultural contradictions of capitalism. London: Heinemann.

Bloom, B., Mesia, B. B., \& Krathwohl, D. R. (1964). Taxonomy of educational objectives. New York: David McKay.

Bock, K. (1979). Theory of progress, development, evolution. In T. Bottomore, \& R. Nisbet (Eds.), A history of sociological analysis. London: Heinemann.

Bourdieu, P. (1997). The forms of capital. In A. H. Halsey, H. Lauder, P. Brown, \& A. S. Wells (Eds.), Education: Culture, economy, and society. Oxford: Oxford University Press.

Cahoone, L. (2003). Introduction. From modernism to postmodernism: An anthology (pp. 1-13). MA.: Blackwell Publishing Company.

Carnoy, M., \& Rhoten, D. (2002). What does globalization mean for educational change? A comparative approach. Comparative Education Review, 1-9.

Castells, M. (2000). End of millennium. ( $2^{\text {nd }}$ ed.). Massachusetts: Blackwell Publishers.

Christie, P., \& Lingard, R. (2001). Capturing complexity in educational leadership. Paper presented to the American Educational Research Association Conference. Seattle: 10-14 April.

Christie, P., \& Sidhu, R. (2002). Responding to globalization: Refugees and the challenges facing Australian schools. Mots Pluriels, 21, May.

Coaldrake, P., \& Stedman, L. (1999). Academic work in the twenty-first century. Canberra: Higher Education Division, Department of Education, Training and Youth Affairs.

Currie, J. (1998). Globalization as an analytical concept and local policy responses. In J. Currie, \& J. Newson (Eds.), Universities and globalization. Thousand Oaks, CA: Sage.

de Saussure, F. (1966). Course in general linguistics (trans. by Wade Baskin). New York: McGraw-Hill.

Delanty, G. (2001). Challenging knowledge: The university in the knowledge society. Philadelphia: SRHE and Open University Press.

Derrida, J. (1973). Speech and phenomena and other essays on Husserl's theory of signs (trans. by David B. Allison). Evanston: North Western University Press.

Edwards, R., \& Usher, R. (1994). Postmodernism and education. London: Routledge.

Flax, J. (1990). Thinking fragments: Psychoanalysis, feminism, and postmodernism in the contemporary West. California: The University of California Press.

Foucault, M. (1977). "Nietzsche, genealogy, history" from "Truth and power". In D. F. Bouchard (Ed.), Language, counter-memory, practice: Selected essays and interviews. New York: Cornell University Press. 
Gilliam, J. C., \& Kritsonis, W. A. (2007). Creative strategies for implementing postmodernism thinking for university administrators to improve colleges and universities in the United States. The Lamar University Electronic Journal of Student Research. Spring.

Girdwood, A. (1997). Quality assurance in higher education: Contexts and trends. Paper presented at the Seminar on Quality Assurance in Higher Education. [Online] Available: http://www.tec.intnet.mu/actentxttedsinter.htm (April 24, 2009)

Harbemas, J. (1987). The philosophical discourse of modernity. Cambridge: Polity.

Hardy, C., \& Palmer, I. (1999). The organizational behavior teaching society. Pedagogical practice and postmodernist ideas. Journal of Management Education, 23(4), 377-395.

Held, D., McGrew, A., Goldbalt, D., \& Perraton, J. (2000). Rethinking globalization. In D. Held, \& A. McGrew (Eds.), The global transformation reader. Cambridge: Polity Press.

Hicks, S. R. C. (2004). Explaining postmodernism: Skepticism and socialism from Rousseau to Foucault. Phoenix/Arizona and New Berlin/Wisconsin: Scholargy Publishing.

Hill, D. (2003). Global neo-liberalism, the deformation of education and resistance. Journal for Critical Education Policy, 1(1), 1-28.

Hutcheson, L. (1989). The politics of postmodernism. London: Routledge.

Jameson, F. (1981). The political unconscious: Narrative as a socially symbolic act. New York: Cornell University Press.

Jencks, C. (1986). The death of modern architecture. In L. Cahoone (Ed.), From modernism to postmodernism (pp. 9-10). MA.: Blackwell Publishing Company.

Kant, I. (1965). Critique of pure reason. New York: St. Martin's Press.

Klages, M. (2007). Literary theory: A guide for the perplexed. [Online] Available: http://www.colorado.edu/English/courses/ENGL2012Klages/pomo.html (January 26, 2010)

Lemke, J. L. (1994). Semiotics and the deconstruction of conceptual learning. [Online] Available: http://academic.brooklyn.cuny.edu/education/jlemke/papers/jsalt.htm (February 4, 2010)

Lingard, B., Hayes, D., Mills, M., \& Christie, P. (2003). Leading learning. London; Philadelphia: Open University Press.

Linn, R. L., \& Gronlund, N. E. (1995). Measurement and assessment in teaching. New Jersey: Prentice Hall, Inc. Lyotard, J. (1984). The postmodern condition: A report on knowledge. Manchester: Manchester University Press.

Marginson, S. (1999). After globalization: Emerging politics of education. Journal of Education Policy, 14(1), 19-31.

Marginson, S. (2004). Competition and markets in higher education: A glonacal analysis. Policy Features in Education, July, 1-59.

Mok, J. K. H., \& Lee, M. H. H. (2003). Globalization or glocalization? Higher education reforms in Singapore. Asia Pacific Journal of Education, 23(1), 15-42.

Nazemzadeh, N., \& Kritsonis, W. A. (2007). Postmodernism, higher education and economics - A different view. The Lamar University Electronic Journal of Student Research, Fall.

Nguyen, M. Q. (2006). Chu nghia hau hien dai: Nhung khai niem can ban (Postmodernism: Basic concepts). Vietnam Net. [Online] Available: http://www3.vietnamnet.vn/vanhoa/tacpham/2006/11/629118/ (January 26, 2010)

Nguyen, V. T. (2000). Vietnam and the issue of continuing higher education reform. Paper presented at the First International Forum on Education Reform. [Online] Available: http://www.worldedreform.com/intercon/kedre16.htm (January 25, 2010)

O'Farrell, C. (1999). Postmodernism for the initiated. In D. Meamore, B. Burnett, \& P. O'Brien (Eds.), Understanding education: Contexts and agendas for the new millennium. Sydney: Prentice Hall.

Oden, T. C. (1992). Two worlds: Notes on the death of modernity in America and Russia. Illinois: InterVarsity Press. 
Phan, D. D. (2000). Von con nguoi (Human capital). Tuoi Tre Chu Nhat (Sunday Youth), 50, 3-4.

Proenza, L. M. (2000). The challenges of globalization. Speech for UA Commencement. [Online] Available: http://www.uakron.edu/president/commencement.php (January 20, 2010)

Sarup, M. (1993). An introductory guide to post-structuralism and postmodernism. Georgia: The University of Georgia Press.

Schon, D. (1995). The new scholarship requires a new epistemology. Change, 27(6), 27-34.

Sim, S. (2005). Introduction to the second edition. The Routledge companion to postmodernism ( $2^{\text {nd }}$ ed.) (pp. vii-xiv). Oxon: Routledge.

Smart, B. (1990). Modernity, postmodernity, and present. In B. S. Turner (Ed.), Theories of modernity and postmodernity. London: SAGE Publications.

Trnavcevic, A. (2004). Schools in the educational markets: The analysis of school publications in Slovenia. Paper presented at the American Educational Research Association 2004 Annual Meeting.

Trodd, C. (2005). Postmodernism and art. In S. Sim (Ed.), The Routledge companion to postmodernism (2 $2^{\mathrm{nd}}$ ed.). Oxon: Routledge.

Ward, G. (2003). Teach yourself: Postmodernism. London: Hodder \& Stoughton.

Waters, M. (2001). Globalization (2 ${ }^{\text {nd }}$ ed.). London: Routledge. 